JEFFEREY SIMONS

\title{
Room Viewing Quadrangle
}

The Grove 3 (1997)

The feet move alone along paths worn in the mind.

A tree, a rock, a stone.

In the eye the room is dark.

The room in the mind shone.

A tree, a rock, a stone.

The soul who knew the room

Views through the room

A tree, a rock, a stone.

\section{What is a syllable}

A pulse, a pop, a peep.

A beat, a bop, a boom.

A cool spurt of doom.

Fe-fie-foe-fumm,

A lip-loosed humm.

A tongue-sprung drum.

A tap, a tone, a tune.

A cool, pearl moon.

A soft touch of air. 


\section{Spinoza and Spermatozoa}

The Grove 25 (2018-2020)

Beautiful Jew, he ground glass so others could see.

Beautiful Jew, he was reviled by Jews and Gentiles

alike. Seeing lucidly the lines, angles, and arcs of

thought, Spinoza wrote systems in fluent theorems.

Demystifying the Scripture, he mystified the mind.

Blessed is to know the mind as one with the world.

Hidden from the eye in 1632, a sole spermatozoon

wombward zoomed. For all such splendid thought,

a single cell swimming toward another in the dark. 


\section{Heat}

I don't breathe smoke, I breathe words on fire.

Sister of the shadow, singer of the shade.

Taster of the dewdrop, knower of the pain.

Hearer of the whisper, healer of the wound.

Bearer of the blossom, child of the womb.

Wearer of the wing, voice of the drum.

Lover of the echo, tuner of the tongue.

Seeker of the halo, seer of the soul.

Speaker of the ember, poet of the glow.

I don't breathe smoke, I breathe words on fire. 


\section{Suite}

\section{Inner Life}

I bend my elbow, wrap my arm

around my eyes

like a scarf.

Light shone years

ago glides and

flows in the center

of my soul,

glowing near

a blood-red drum.

\section{Surprise Visit}

Night swept over the rim of the globe.

Beyond a glowing

\section{Rude People on the Road}

Let the moon beam

through the rude

people on the road,

those honkers and hooters

steaming behind

their smoking steering

wheels. Let the moonlight, tracing the crests

of groves and the crisp arc of land,

beam through to stop

them in their tracks.

doorway - the light within shone out-

stands the lone

figure I see: a woman awaiting one of her making. 


\section{Male Aging}

Men folk ought

not to be wholly

dismissed. This is

especially so

now that they

are so easily

deplored.

Take male aging.

This begins

with a thickening

of the eyebrows,

stray wild wires

to be trimmed or

plucked.

Another sign

arises in the wee

hours of the night,

when they sit

to pee. Definitive

proof occurs

in the cool muting

of being.

Take note

of the aging male, known for what he has done.

\section{Fine Notion}

When the body

dies, a mind

dies. There's no

diving in

to scoop up

the knowing

that goes.

This

is an idea

to live by.

\section{End of the Line}

What awaits us there is death,

the chrysalis of dawn,

silent like a butterfly's wing.

\section{Elide and Glide}

Enough minstrelsy and psalmody!

Elide and glide!

Let the silence decide.

Jefferey Simons teaches in the Department of English Philology at the University of Huelva. His essays on the poetry of Emily Dickinson have appeared in European Journal of American Studies (2017), The Emily Dickinson Journal (2019), and Amerikastudien / American Studies (2020). Other essays on the poetry and prose of James Joyce have appeared in Joyce Studies Annual (2002, 2013, 2018), European Journal of English Studies (2007), Genetic Joyce Studies (2010), and James Joyce Quarterly (2014). 
